\title{
POST-SPILL ECOLOGICAL HEALTH ASSESSMENT AT THE SOUTHERN COAST OF MACTAN ISLAND, PHILIPPINES USING MULTIMETRIC PHYTOPLANKTON INDEX FOR BIOTIC INTEGRITY
}

\author{
Edullantes, B. ${ }^{*}$ - SaÑoza, W. - VARgas, C. - SAngutan, S. - Pocong, M. - Silapan, J. \\ Department of Biology and Environmental Science, College of Science, University of the \\ Philippines Cebu, Lahug, Cebu City, Cebu 6000, Philippines \\ *Corresponding author \\ e-mail: bedullantes@up.edu.ph; phone: +63-32-233-398
}

(Received $9^{\text {th }}$ Nov 2020; accepted $8^{\text {th }}$ Feb 2021)

\begin{abstract}
Evaluation of ecological health status after an oil spill is crucial for effective restoration measures of the affected aquatic ecosystems. In this study, we applied a multimetric phytoplankton index for biotic integrity (MPI-BI) to assess the ecological health status of the southern coast of Mactan Island, Philippines after 8, 12, 24, and 30 months from the MV Thomas Aquinas spill incident in August 2013. Phytoplankton community analysis revealed (1) no difference in abundance, richness, and diversity between affected and reference sites, (2) increasing trend of diversity over time after the spill, and (3) higher remotely-sensed chlorophyll $a$ level in affected sites. Phytoplankton relative abundance, diversity, and trophic state were used to derive MPI-BI. Based on MPI-BI, the health status of the affected sites was generally in good condition $8-30$ months after. A time-series analysis of remotely-sensed and meteorological parameters showed no difference between pre and post spill conditions, except for chlorophyll $a$ and particulate organic carbon. Generally, the health status of the coastal water may be affected by the oil spillage as indicated by the increased trophic state after the spill but may be recovering from the oil spill stress.

Keywords: phytoplankton community, bioindicator, oil spill impact, multivariate analysis, remote sensing application
\end{abstract}

\section{Introduction}

Discharge of oils into marine ecosystems due to accidental spillage has been a major environmental issue for several decades and a major contributor to the instability of the marine ecosystem worldwide (Farrington, 2013). Oil spill events disturb the complex ecological interactions that subsequently decrease the integrity of water quality to support aquatic life (Farrington, 2014). Similar to any other anthropogenic perturbations, these incidents also degrade the sustainable human use of the coastal ecosystems resulting in the economic loss (García Pérez, 2003; Surís-Regueiro et al., 2007). It is, therefore, crucial to assess the ecological health status of aquatic ecosystems after an oil spill to provide information for effective restoration measures (IMO/UNEP, 2009). Biological indicators have been used as the main tool for ecological health assessment after the spill (e.g. Gesteira and Dauvin, 2000; Bolognesi et al., 2006). These are quantifiable biological features that are sensitive to environmental perturbation. Most assessments are often concentrated on oil spill impacts in the coastal, mangrove, and sublittoral areas where the effect is very much noticeable as compared to the pelagic and planktonic organisms (Parsons et al., 2015).

Phytoplankton is a diverse group of microscopic, single-celled organisms that are ubiquitous in aquatic environments (Reynolds, 2006). Their ecological role of providing energy to the next trophic level (Falkowski, 2012) may be disrupted when a high level 
of spilled oil floats at the upper layer of the water column (Gin et al., 2001). The presence of oil can cause a fairly rapid and marked reduction in the abundance of certain species, and possibly a proliferation of other species (Hallare et al., 2011; Ozhan et al., 2014). The sensitivity of phytoplankton to anthropogenic pressures makes them a reliable biological indicator of the ecological health status of an aquatic environment (Verlecar et al., 2006). Phytoplankton diversity indices and the other single biotic index methods have been used to assess aquatic ecological health status (El-Sheekh et al., 2000; Suderman and Thistle, 2004; Hallare et al., 2011). Although these methods are easier and faster to perform, they are incomprehensive and incomplete because they reflect limited information of environmental changes (Teng et al., 2014). The ecological health status entails pressure-independent assessment and can be attained by using pressure-specific multimetric indices (Barbour et al., 2000). The multimetric approach typically involves two phases: (1) development phase where metrics are selected, calibrated and aggregate into an index, and (2) evaluation phase where the index is used to assesses ecological condition at sites and evaluate impairment (Barbour et al., 2000). This approach can be used to determine the ecological health status of coastal waters that are exposed to anthropogenic perturbations like oil spills.

Chlorophyll $a$ is a vital component of phytoplankton primary production and is often used as a measure to indirectly estimate the biomass. Measurement of the chlorophyll $a$ concentration ( $\mathrm{Chl} a$ ) is also important monitoring the phytoplankton distribution in seawater surface to understand wide-scoped biological processes. Large-scale observations of $C h l a$ can be conducted in near real-time by satellite remote sensing compared to laboratory analysis and traditional ship surveys that are limited to small spatiotemporal coverage and are time-consuming (Behrenfeld and Falkowski, 1997). Satellite remote sensing has been used in a recent study to evaluate whether the Chl $a$ was affected by the Deepwater Horizon oil spill in the northern Gulf of Mexico over a multi-year time period (Li et al., 2019).

The collision between MV St. Thomas Aquinas and MV Sulpicio Express Siete in August 2013 discharged 20,000 liters of diesel, 120,000 liters of bunker or crude oil, and 20,000 liters of lube oil into the coastal waters in Talisay, Cebu, Philippines. The leaked oil was carried by the southwest monsoon winds to the coastal areas in the southern part of Mactan Island. This contaminated the fishing grounds, aquaculture ponds, and beaches of the affected areas. Previous studies have documented the impact of this oil spill on mangrove communities (Sadaba and Niego, 2016), bacterial composition (Bensig et al., 2014), and zooplankton abundance (Flores et al., 2020). No studies have been published yet that assess the phytoplankton communities after the oil spill incident.

This study aimed to assess the ecological health status of the southern coastal waters of Mactan Island after the MV Thomas Aquinas oil spill incidence using a multimetric phytoplankton index. Working under the overall hypothesis that the ecological health status declines after the oil spill, we focused on answering three research questions: (1) How does the phytoplankton community structure in affected sites differ in a reference condition after the spill incident? (2) What is the post-spill health status in the affected sites based on the multimetric phytoplankton index for biotic integrity? (3) Does the oil spill cause the post-spill pattern of phytoplankton in the affected sites? In this paper, we described patterns of variation in phytoplankton community structure in the oil spill affected areas using multivariate analysis. The correlative trends were used to identify significant variables for the development of the multimetric phytoplankton index to 
assess the affected sites' ecological health status after the spill. Finally, we analyzed available meteorological data and remotely sensed data to examine whether the pattern in the phytoplankton-based health status is caused by the oil spill or by natural variability caused by meteorological conditions.

\section{Methodology}

\section{Study sites}

Three sites off the coast of southern Mactan Island, Philippines were selected in terms of the extent of MV Thomas Aquinas oil spill impact (Fig. 1). These were the coastal areas in Alegria $\left(\mathrm{S} 1 ; 10^{\circ} 14^{\prime} 56.43^{\prime \prime} \mathrm{N}, 123^{\circ} 58^{\prime} 4.79^{\prime \prime} \mathrm{E}\right)$, Calawisan (S2; 10 $16^{\prime} 20.23^{\prime \prime} \mathrm{N}$, $\left.123^{\circ} 55^{\prime} 2.90^{\prime \prime} \mathrm{E}\right)$ and Day-as (S3; 10 $\left.15^{\prime} 17.23^{\prime \prime} \mathrm{N}, 123^{\circ} 55^{\prime} 28.90^{\prime \prime} \mathrm{E}\right)$, which were identified to have low, mid and high oil spill impact status, respectively (Bensig et al., 2014; Flores et al., 2020). The offshore water in Dalaguete was chosen as a reference site (Ref; $9^{\circ} 45^{\prime} 57.34^{\prime \prime} \mathrm{N}, 123^{\circ} 33^{\prime} 2.60^{\prime \prime E}$ ). Ref was not affected by the oil spill, and it has similar features with the affected sites in Mactan, i.e. presence of fringing mangroves and seagrass meadows. Ref is about $97 \mathrm{~km}$ away from the oil spill affected areas.

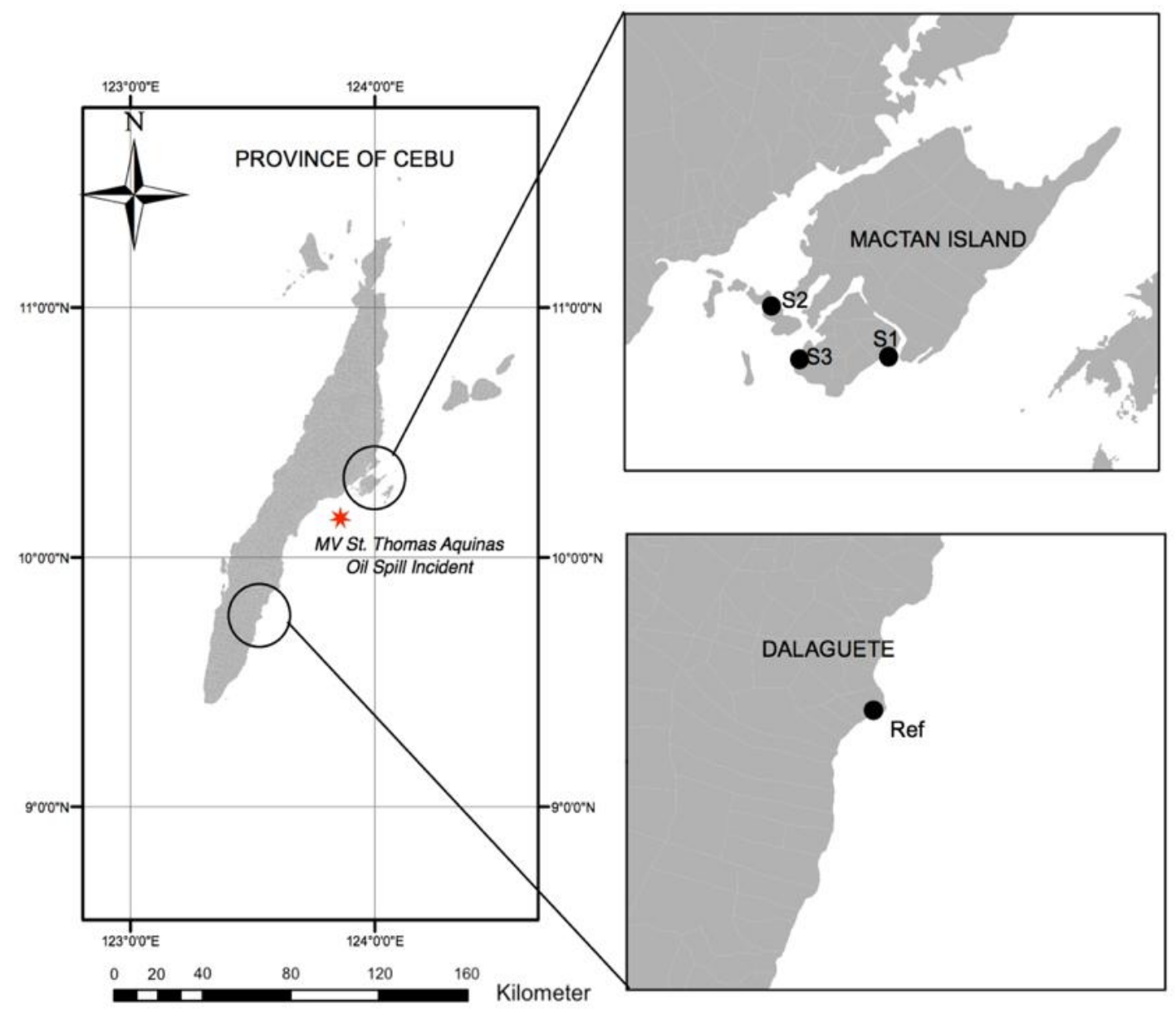

Figure 1. The sampling sites in Barangays Alegria (S1), Calawisan (S2), and Day-as (S3) in Mactan Island, and the reference site (Ref) in Dalaguete, Cebu, Philippines 


\section{Sampling}

In each site, three random points were established for water sampling. The samplings were conducted in May and August 2014, August 2015, and March 2016 (8, 12, 24, and 30 months after the oil spill, respectively). The water samples were collected at $0.5 \mathrm{~m}$ below the surface. The samples were placed into $1 \mathrm{~L}$ sample bottles and were preserved immediately with $5 \mathrm{~mL}$ of Lugol's solution, and were brought to the laboratory for analysis.

\section{Phytoplankton community structure analysis}

Water samples were set aside for at least $24 \mathrm{~h}$ to allow phytoplankton to settle at the bottom. Subsequently, 0.9 L sample was carefully siphoned from the surface. The remaining $0.1 \mathrm{~L}$ concentrated algal sample was homogenized before $1 \mathrm{~mL}$ aliquot of the sample was subjected for enumeration of the phytoplankton under a compound light microscope. The drop-count method was used to examine the aliquot one to two drops at a time following the protocol of Verlecar and Desai (2004). The species were identified and verified using the AlgalBase (Guiry and Guiry, 2016). Abundance, relative abundance, diversity indices at the species level (Eq.1 to Eq.7) were included in the quantitative description of the phytoplankton community structure of the study sites (Table 1).

Table 1. Description of the different metrics of the phytoplankton community structure

\begin{tabular}{|c|c|c|}
\hline Metrics & Equations/Unit & \\
\hline Total Abundance (ind L-1) & $N=$ total $\#$ of individuals & (Eq.1) \\
\hline Relative abundance of diatoms (\%) & Dia $=\#$ of diatoms $* 100 / \mathrm{N}$ & (Eq.2) \\
\hline Relative abundance of dinoflagellates $(\%)$ & Dino $=\#$ of dinoflagellates $* 100 / \mathrm{N}$ & (Eq.3) \\
\hline Relative abundance of cyanobacteria (\%) & $C y a=\#$ of cyanobacteria $* 100 / \mathrm{N}$ & (Eq.4) \\
\hline Species Richness ${ }^{b}$ & $S=\#$ of species & (Eq.5) \\
\hline Shannon's diversity index ${ }^{b}$ & $H^{\prime}=-\Sigma\left(\mathrm{n}_{\mathrm{i}} / \mathrm{N}\right) \ln \left(\mathrm{n}_{\mathrm{i}} / \mathrm{N}\right)^{\mathrm{a}}$ & (Eq.6) \\
\hline Pielou's evenness ${ }^{\mathrm{b}}$ & $J=\mathrm{H}^{\prime} / \log (\mathrm{S})$ & (Eq.7) \\
\hline Phytoplankton biomass ${ }^{\mathrm{c}}$ & Chl $a, \mathrm{mg} \mathrm{m}^{-3}$ & \\
\hline
\end{tabular}

${ }^{a} n_{i}$ is the number of individuals of the $i^{\text {th }}$ group in the sample

${ }^{b}$ calculated using the vegan package in R (Oksanen et al., 2019)

${ }^{\mathrm{c}}$ chlorophyll a as proxy, which is extracted from Aqua-MODIS monthly Level- 3 estimates as described below

Principal Component Analysis (PCA) was used to explore the pattern of variation of phytoplankton community structure using the matrix that contains 48 observations ( 3 sampling points $\mathrm{x} 4$ sites $\mathrm{x} 4$ sampling dates) and 8 phytoplankton variables (as listed in Table 1). The data were log-transformed to normalize the data distribution. Kolmogorov-Smirnov test was used to determine the normality of the data. The data were centered since the variables were measured in the different scale and were standardized because PCA is sensitive to the relative scaling of the original variable. The relationship between the eight phytoplankton variables was determined using the Pearson correlation coefficients. The resulting correlation matrix was used to extract the principal axes, and only those axes that explained significantly the total variance were selected for 
interpretation. ANOVA and pairwise comparison using t-test were used to test differences between the reference and affected sites.

\section{Derivation of Multimetric Phytoplankton Index for Biotic Integrity (MPI-BI)}

The results of the PCA was used to select variables that best illustrated the variation captured by each axis. Variables whose loadings were higher than 0.45 were selected for the development of the Multimetric Phytoplankton Index for Biotic Integrity (MPI-BI). Each of the selected variables was used to compute for the Ecological Quality Ratio (EQR) using Eq.8. For phytoplankton biomass data, EQR was calculated using Eq.9. The range of the EQR scores was set from 0 to 1 . The MPI-BI score was computed by averaging all the EQR scores at each sampling point (Eq.10). A higher MPI-BI score indicates better health of the affected the site. MPI-BI were then compared among oil spill affected sites.

$$
\begin{gathered}
\mathrm{EQR}_{\mathrm{i}}=\mathrm{x}_{\mathrm{i}} \text { in affected site } / \mathrm{x}_{\mathrm{i}} \text { in reference site } \\
\mathrm{EQR}_{\mathrm{j}}=\mathrm{x}_{\mathrm{j}} \text { in reference site } / \mathrm{x}_{\mathrm{j}} \text { in affected site } \\
\mathrm{MPI}-\mathrm{BI}=\Sigma \mathrm{EQR}_{\mathrm{i}} / \text { no. of metrics }
\end{gathered}
$$

where $x$ is the observed value of the variable in an affected site $i$ and reference $j$.

\section{Assessment of meteorological and satellite-based data}

Aqua-MODIS monthly Level- 3 estimates of chlorophyll $a\left(C h l a, \mathrm{mg} \mathrm{m}^{-3}\right)$, particulate organic carbon $\left(P O C, \mathrm{mg} \mathrm{m} \mathrm{m}^{-3}\right.$ ), sea surface temperature (SST, deg C), and photosynthetically active radiation $\left(P A R\right.$, einstein $\left.\mathrm{m}^{-2} \mathrm{~d}^{-1}\right)$ were obtained from NASA Distributed Active Archive Center (http://oceancolor.gsfc.nasa.gov/). The spatial resolution of these data was $4 \mathrm{~km}^{2}$, and temporal resolution was monthly from 2012-2015. Monthly estimates of $C h l a, P O C, S S T$, and $P A R$ in all the study sites were extracted using SeaDAS software version 7.3.2 (Baith et al., 2006; https://seadas.gsfc.nasa.gov/). All remotely sensed data in the affected sites were pooled and reported as mean mean $\pm \mathrm{SE}$. Air temperature $(A T, \operatorname{deg} \mathrm{C})$, relative humidity $(R H, \%)$, precipitation $(P, \mathrm{~mm})$, and mean sea level pressure (MSLP, hpa) were obtained from Philippine Atmospheric Geophysical and Astronomical Services Administration (PAGASA) - Department of Science and Technology (DOST). These meteorological data were measured in the Mactan station. The temporal resolution of this data was daily from 2012-2015. Monthly average values of these meteorological parameters were computed and reported as mean \pm SEM. PCA was also applied to examine the variability of the monthly estimates of remotely sensed and meteorological parameters using the matrix that contains 48 observations (12 months $\mathrm{x} 4$ years) and 8 parameters.

\section{Data processing and analysis}

Descriptive statistics were determined to summarize the collected data. All averaged values were reported as mean \pm SEM. PCA, ANOVA, Pearson correlation, and Welch ttest were carried out using the stat $\mathrm{R}$ package (R Core Team, 2019). 
Data wrangling and visualization were implemented in $\mathrm{R}$ version 3.3.2 (R Core Team, 2019) software using the following packages: tidyverse (Wickham et al., 2019), maps (Becker et al., 2018), raster (Hijmans, 2020), and ggthemes (Arnold, 2019).

\section{Results}

\section{Pattern of variation in phytoplankton community structure}

The affected sites revealed the dominance of three major taxonomic groups - diatoms dominated with pooled mean relative abundance of $62.0 \pm 8.4 \%, 54.3 \pm 7.8 \%$, $83.6 \pm 2.5 \%$, and $50.4 \pm 11.0 \%$ after $8,12,24$ and 30 months from the oil spill incident, respectively; followed by dinoflagellates $(25.5 \pm 7.6 \%, 32.6 \pm 7.7 \%, 10.8 \pm 2.5 \%$, and $46.38 \pm 12.0 \%$, respectively); and then by cyanobacteria $(12.5 \pm 7.5 \%, 13.1 \pm 6.0 \%, 2.6 \pm$ $0.8 \%$, and $2.0 \pm 0.8 \%$, respectively).

For all samples in affected sites, diatoms were comprised of five classes, i.e. Bacillariophyceae (17 orders, 28 families, 64 genera, and 124 species), Coscinodiscophyceae (7 orders, 9 families, 11 genera, and 13 species), Mediophyceae (6 orders and families, and 8 genera and species), Biddulphiophycidae ( 2 genera, and 4 species), and Fragilariophyceae (1 species); dinoflagellates were represented by two classes (Dinophyceae ( 7 orders, 16 families, 23 genera, and 33 species) and Noctilucophyceae (1 species); and cyanobacteria were composed by class Cyanophyceae ( 5 orders and families, 6 genera and 7 species). Several diatoms ( 9 orders, 13 families, 36 genera, and 74 species), dinoflagellates ( 2 orders, 5 families, 10 genera, and 15 species), and cyanobacteria ( 3 orders and families, 4 genera, and 5 species) are present in affected sites and not found in the reference site. However, 6 diatom species and none of the dinoflagellate and cyanobacteria in the reference site were absent in the affected sites.

ANOVA showed a significant difference in the relative abundance of diatoms (Dia), dinoflagellates (Dino), and cyanobacteria $(C y a)$, Pielou's evenness $(J)$, and phytoplankton biomass ( Chl a) among sites (Table 2). Pairwise comparisons using t-tests confirmed the significant difference in these parameters between the reference and affected sites after a certain period from the oil spill incident (Fig. 2). Among these sitespecific parameters, $C h l a$ in all affected sites were significantly higher than the values in the reference condition, suggesting that this parameter is pressure-specific. A significant temporal variation was observed in $C y a, S$ (species richness), and $H$ (Shannon's diversity index) that showed to increase after $8-24$ months from the spill (Table 2). A two-way ANOVA revealed evidence of a significant interaction effect between spatial and temporal scales at which the $N$ (total abundance), Dino, Cya, and Chl $a$ were sampled (Table 2).

We applied PCA to obtain further information on the pattern of variation in phytoplankton community structure. Fig. 3 shows the progressive decline of principal components' (PC) eigenvalues and the proportion of explained variances. The last four PCs represented a small proportion of the total variance $(<6.5 \%)$ and were not included in the interpretation. Four significant PC axes were obtained and revealed that PC1 - PC4 explained $39.1 \%, 22.6 \%, 15.4 \%$, and $9.4 \%$ of the total variance, respectively. These PCs accounted for $86.5 \%$ of the total variance explained, while $13.5 \%$ of the variance remained unexplained. Fig. 4 illustrates the projections of the phytoplankton variables of the reference and affected sites 8, 12, 24, and 30 months after the spill. 
Table 2. Summary statistics of the analysis of variance (ANOVA) conducted to examine the spatial and temporal variation in total abundance of phytoplankton $(N)$, relative abundance of diatoms (Dia), dinoflagellates (Dino), and cyanobacteria (Cya), species richness $(S)$, Shannon's diversity index (H), Pielou's evenness (J), and phytoplankton biomass (Chl a)

\begin{tabular}{|c|c|c|c|c|c|c|c|}
\hline ANOVA Models & Terms & df & Sum Sq. & Mean Sq. & F value & p-value & \\
\hline \multirow{4}{*}{$N \sim$ Site $\mathrm{x}$ Date } & Site & 3 & 1132406.25 & 377468.75 & 1.00 & 0.40 & \\
\hline & Date & 1 & 3533.75 & 3533.75 & 0.01 & 0.92 & \\
\hline & Site:Date & 3 & 4545894.63 & 1515298.21 & 4.02 & 0.01 & $*$ \\
\hline & Residuals & 40 & 15083963.29 & 377099.08 & & & \\
\hline \multirow{4}{*}{ Dia $\sim$ Site x Date } & Site & 3 & 13452.61 & 4484.20 & 12.47 & $<0.01$ & $*$ \\
\hline & Date & 1 & 390.42 & 390.42 & 1.09 & 0.30 & \\
\hline & Site:Date & 3 & 1797.76 & 599.25 & 1.67 & 0.19 & \\
\hline & Residuals & 40 & 14386.37 & 359.66 & & & \\
\hline \multirow{4}{*}{ Dino $\sim$ Site $\mathrm{x}$ Date } & Site & 3 & 12251.86 & 4083.95 & 11.71 & $<0.01$ & $*$ \\
\hline & Date & 1 & 0.39 & 0.39 & $<0.01$ & 0.97 & \\
\hline & Site:Date & 3 & 3120.00 & 1040.00 & 2.98 & 0.04 & $*$ \\
\hline & Residuals & 40 & 13954.76 & 348.87 & & & \\
\hline \multirow{4}{*}{ Cya $\sim$ Site x Date } & Site & 3 & 2937.16 & 979.05 & 22.66 & $<0.01$ & $*$ \\
\hline & Date & 1 & 616.42 & 616.42 & 14.27 & $<0.01$ & $*$ \\
\hline & Site:Date & 3 & 2882.67 & 960.89 & 22.24 & $<0.01$ & $*$ \\
\hline & Residuals & 40 & 1727.89 & 43.20 & & & \\
\hline \multirow{4}{*}{$S \sim$ Site x Date } & Site & 3 & 768.90 & 256.30 & 1.92 & 0.14 & \\
\hline & Date & 1 & 6042.16 & 6042.16 & 45.19 & $<0.01$ & $*$ \\
\hline & Site:Date & 3 & 342.04 & 114.01 & 0.85 & 0.47 & \\
\hline & Residuals & 40 & 5347.88 & 133.70 & & & \\
\hline \multirow{4}{*}{$H \sim$ Site $\mathrm{x}$ Date } & Site & 3 & 1.06 & 0.35 & 0.69 & 0.56 & \\
\hline & Date & 1 & 7.39 & 7.39 & 14.44 & $<0.01$ & $*$ \\
\hline & Site:Date & 3 & 3.78 & 1.26 & 2.46 & 0.08 & \\
\hline & Residuals & 40 & 20.46 & 0.51 & & & \\
\hline \multirow{4}{*}{$J \sim$ Site $\mathrm{x}$ Date } & Site & 3 & 0.19 & 0.06 & 3.65 & 0.02 & $*$ \\
\hline & Date & 1 & 0.05 & 0.05 & 2.85 & 0.10 & \\
\hline & Site:Date & 3 & 0.13 & 0.04 & 2.49 & 0.07 & \\
\hline & Residuals & 40 & 0.70 & 0.02 & & & \\
\hline \multirow{4}{*}{ Chl $a \sim$ Site x Date } & Site & 3 & 1.69 & 0.56 & 27.38 & $<0.01$ & $*$ \\
\hline & Date & 1 & 0.03 & 0.03 & 1.39 & 0.25 & \\
\hline & Site:Date & 3 & 0.35 & 0.12 & 5.65 & $<0.01$ & $*$ \\
\hline & Residuals & 40 & 0.82 & 0.02 & & & \\
\hline
\end{tabular}

Notes: asterisk * indicates significance at $95 \%$ confidence interval

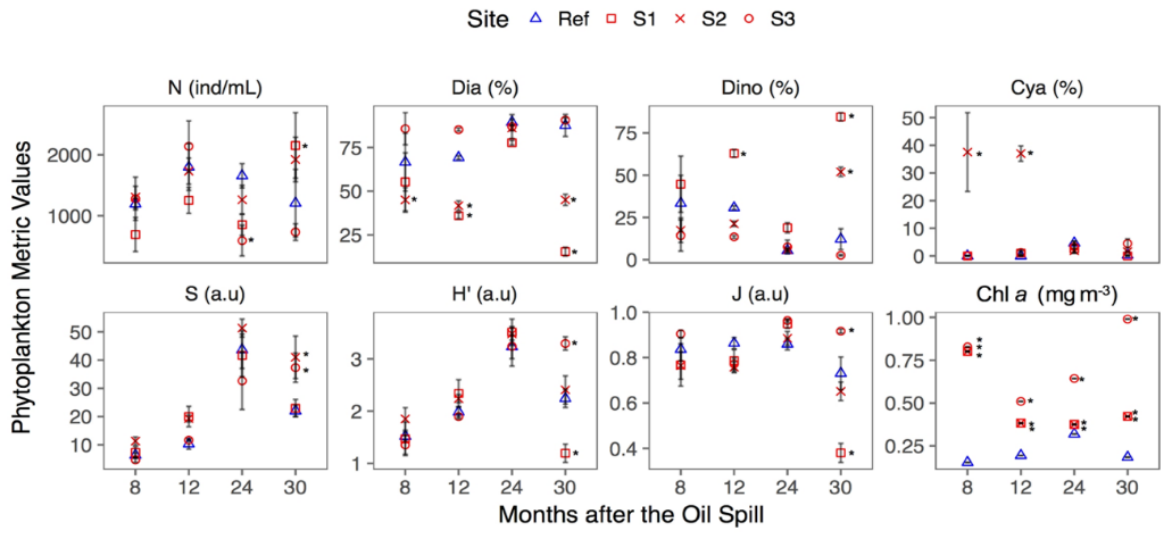

Figure 2. Variation of $(A)$ total phytoplankton biomass, relative abundance of $(B)$ diatoms, $(C)$ dinoflagellates, $(D)$ cyanobacteria, $(E)$ species richness, $(F)$ Shannon's diversity index, $(G)$ species evenness, and $(H)$ chlorophyll a levels (mean $\pm S E$ ) in the reference and affected sites after 8 - 30 months from the oil spill incident. An asterisk (*) indicates a significant difference $(p<0.05)$ to the mean value in the reference site 


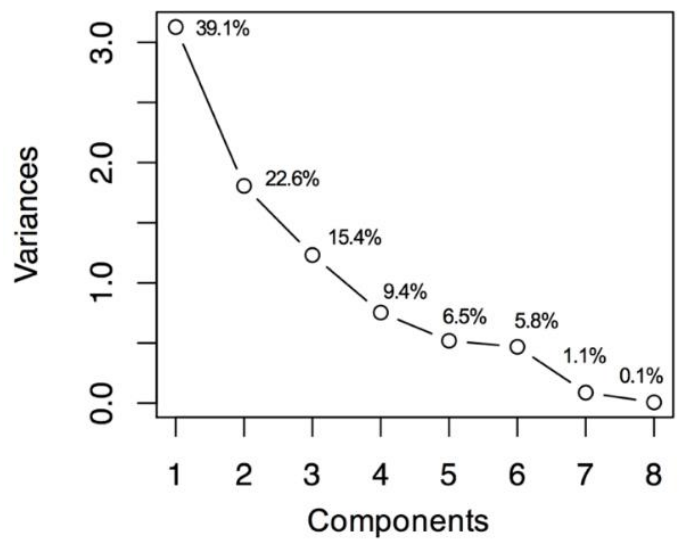

Figure 3. Scree plot of the percent of variance explained by each principal component
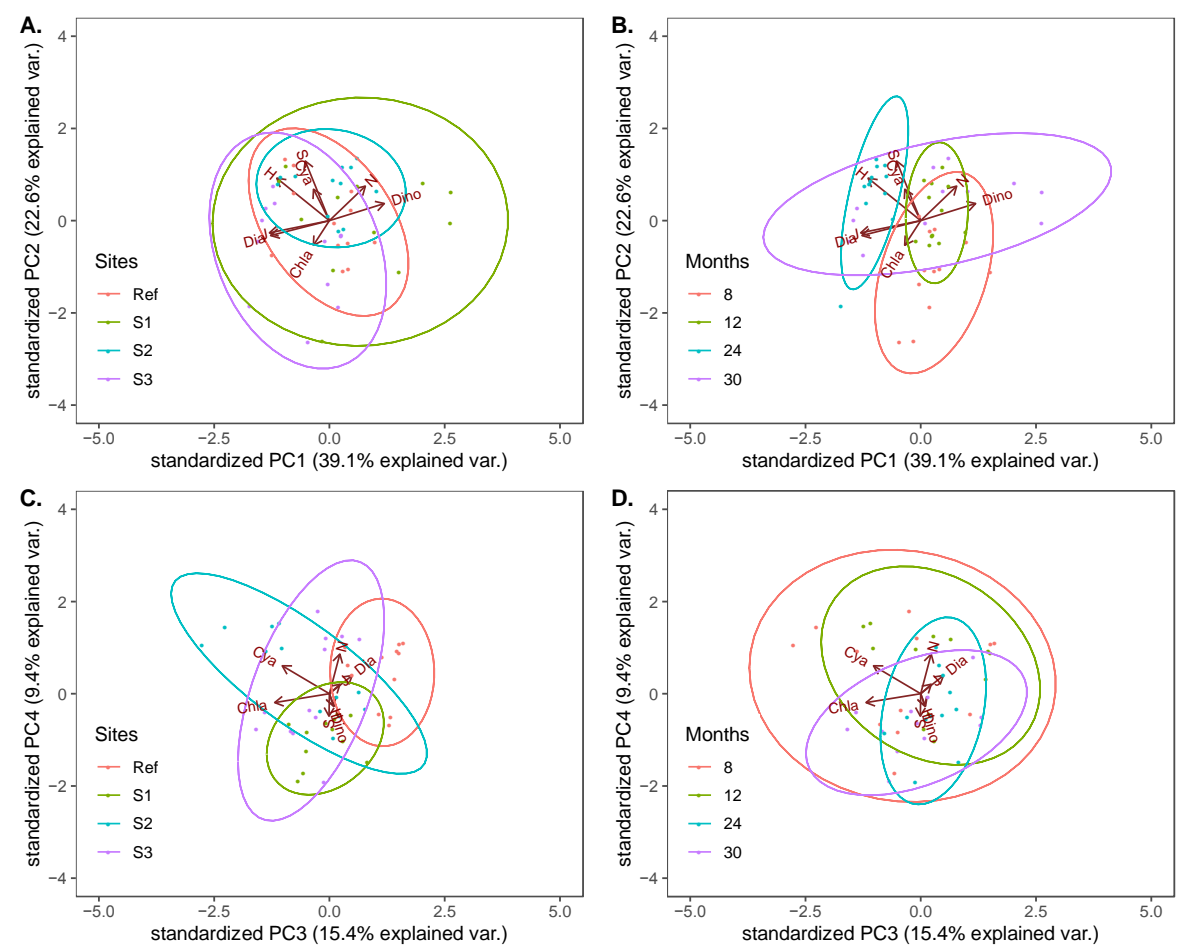

Figure 4. Projection of the eight phytoplankton variables on the $(A-B) P C 1$ and PC2 axes, and $(C-D) P C 3$ and PC4 axes. Ellipses (95\% confidence) represent the projections of the variables sampled in reference and affected sites after $8-30$ months from the oil spill

Fig. 5 shows the temporal changes in PC eigenvalues between reference and affected sites. PC1 relates to the relative abundance of phytoplankton as it best explained the variability of Dia, Dino, and $J$ with Pearson correlation coefficients $(r)$ of $0.48,-0.45$, and 0.49 , respectively. This suggests that Dia and $J$ decrease with increasing PC1 eigenvalues, while Dino increase with decreasing PC1 eigenvalues. PC2, on the other hand, relates to the phytoplankton diversity as the variability of $S$ and $H$ ' were best explained by this axis. Both variables had a positive correlation with PC2 eigenvalues with $r$ values of 0.64 and 0.45 , respectively. PC3 was negatively related to $C h l a(r=-0.71)$ and is related to the trophic state. PC4 was positively related to $N(r=0.66)$ and Cya $(r=0.46)$. 


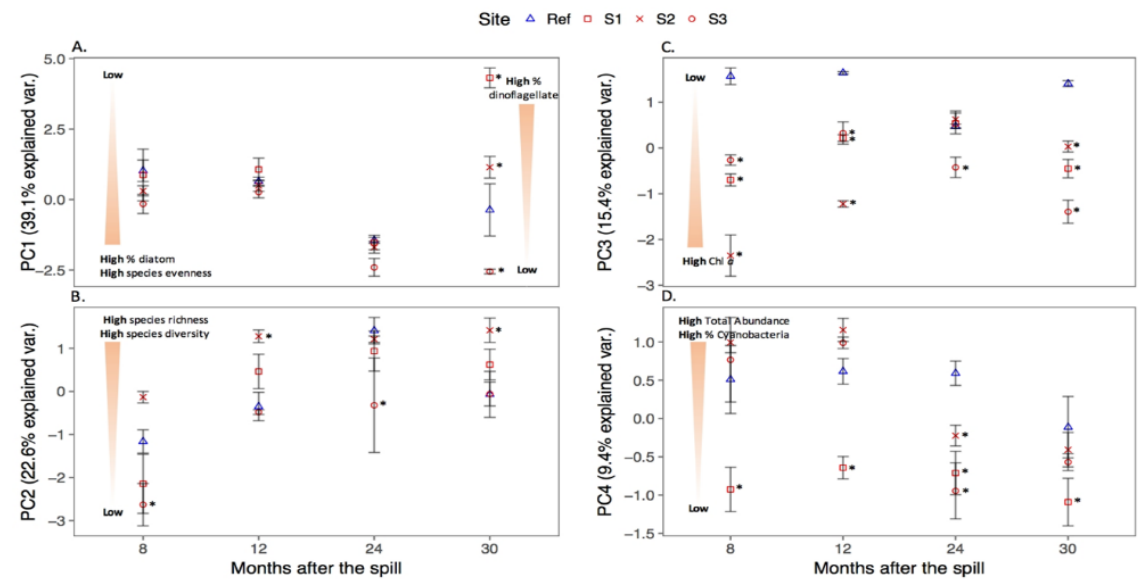

Figure 5. Variation of the PC1 - PC4 eigenvalues (mean $\pm S E ; A-D$, respectively) in the reference and affected sites after 8 - 30 months from the oil spill incident. An asterisk (*) indicates a significant difference $(p<0.05)$ to the mean value in the reference site

ANOVA showed significant spatial variation in PC1, PC2, PC3, and PC4 axes, but only PC2 and PC4 axes did vary significantly (Table 3). Fig. 5 displayed the significant difference in the PC eigenvalues between the reference and affected sites after a certain period from the oil spill incident. The findings suggest that the relative abundance of phytoplankton and trophic state differ across sites, while diversity varies both spatially and temporally. PC3 eigenvalues in the Ref vary significantly to the values in S1, S2, and S3 after 8, 12, and 30 months from the spill, suggesting a higher trophic state in the oil spill affected sites. Also, PC2 eigenvalues observed in 8 months were significantly different from the observations in 12, 24 and 30 months after the oil spill, implying a higher phytoplankton diversity within these periods.

Table 3. Summary statistics of the analysis of variance (ANOVA) conducted to examine the spatial and temporal variation in PC1 to PC4 axes and in Multimetric Phytoplankton Index for Biotic Integrity (MPI-BI)

\begin{tabular}{|c|c|c|c|c|c|c|c|}
\hline ANOVA Models & Terms & df & Sum Sq. & Mean Sq. & F value & p-value & \\
\hline \multirow{4}{*}{$\mathrm{PC} 1 \sim$ Site $\mathrm{x}$ Date } & Site & 3 & 34.51 & 11.50 & 5.67 & $<0.01$ & $*$ \\
\hline & Date & 1 & 4.19 & 4.19 & 2.07 & 0.16 & \\
\hline & Site:Date & 3 & 27.17 & 9.06 & 4.47 & 0.01 & $*$ \\
\hline & Residuals & 40 & 81.12 & 2.03 & & & \\
\hline \multirow{4}{*}{ PC2 $~$ Site $\mathrm{x}$ Date } & Site & 3 & 19.89 & 6.63 & 6.20 & $<0.01$ & $*$ \\
\hline & Date & 1 & 20.95 & 20.95 & 19.60 & $<0.01$ & $*$ \\
\hline & Site:Date & 3 & 1.32 & 0.44 & 0.41 & 0.75 & \\
\hline & Residuals & 40 & 42.74 & 1.07 & & & \\
\hline \multirow{4}{*}{ PC3 $\sim$ Site $\mathrm{x}$ Date } & Site & 3 & 28.26 & 9.42 & 27.33 & $<0.01$ & $*$ \\
\hline & Date & 1 & 0.35 & 0.35 & 1.03 & 0.32 & \\
\hline & Site:Date & 3 & 15.49 & 5.16 & 14.98 & $<0.01$ & $*$ \\
\hline & Residuals & 40 & 13.79 & 0.34 & & & \\
\hline \multirow{4}{*}{ PC4 Site x Date } & Site & 3 & 12.22 & 4.07 & 15.18 & $<0.01$ & $*$ \\
\hline & Date & 1 & 8.68 & 8.68 & 32.36 & $<0.01$ & $*$ \\
\hline & Site:Date & 3 & 3.79 & 1.26 & 4.71 & 0.01 & $*$ \\
\hline & Residuals & 40 & 10.73 & 0.27 & & & \\
\hline \multirow{4}{*}{ MPI-BI Site x Date } & Site & 3 & 0.77 & 0.26 & 21.04 & $<0.01$ & $*$ \\
\hline & Date & 1 & $<0.01$ & $<0.01$ & 0.18 & 0.68 & \\
\hline & Site:Date & 3 & 0.03 & 0.01 & 0.73 & 0.54 & \\
\hline & Residuals & 40 & 0.49 & 0.01 & & & \\
\hline
\end{tabular}

Notes: asterisk $*$ indicates significance at $95 \%$ confidence interval 
PCA was successfully demonstrated in this study as a useful and effective tool to decrease the number of phytoplankton parameters to explain the variation observed between the reference and affected sites after $8-30$ months from the spill. The reduction of the number of variables did not impair the quality of the information in this study as the PCA agrees with the previous analysis. The PCA results revealed that the variation in the observations can be best explained by the phytoplankton relative abundance (Dia, Dino, and $J)$, phytoplankton diversity $(S$ and $H)$, and trophic state $(C h l a)$. All these parameters were site-specific, but only the trophic state showed pressure-specificity.

\section{Assessment of health status using MPI-IB}

Based on the PCA results, the variables that explained the variation captured by each axis were selected. Out of eight components, PC1, PC2, and PC3 were selected as they provide a meaningful explanation of the variability of phytoplankton relative abundance, diversity, and trophic state, respectively. The variables that significantly correlated with each of the selected PC were extracted. Only six out of eight variables met this requirement and were retained for the development of MPI-BI. Each metric represents a unique biological feature and plays a distinct role in the MPI-IB. For instance, diatom dominated in oil spill affected sites, and hence, the relative abundance of diatom deserves attention when assessing the ecological health status of coastal water after the oil spill. These metrics represent ecological quality changes and can explain the degree of stress after the oil spill. In each of these variables, the Ecological Quality Ratio (EQR) was computed to determine the degree of departure of the metric value in the affected site from the value in the reference site. These scores were averaged to determine MPI-BI scores. The MPI-BI range was equally divided into 5 ecological health status: (1) High (0.81 - 1.0), (2) Good (0.61 - 0.80), (3) Moderate $(0.41-0.60)$, (4) Poor $(0.21-0.40)$, and, (5) $\mathrm{Bad}(0-0.20)$. The high condition indicates that the environment is characterised by low trophic state due to low chlorophyll $a$ levels, and high species richness and evenness that results in high diversity. At the other extreme, bad condition indicates environment with high trophic state due to high chlorophyll $a$ levels, and low biodiversity due to low richness and uneven distribution of phytoplankton. MPI-BI scores of the affected sites were generally above 0.6 , suggesting that the health status of the affected sites were in good to high condition after $8-30$ months from the oil spill incident (Fig. 6). Variation in MPI-BI was evident spatially but not temporally (Table 3).

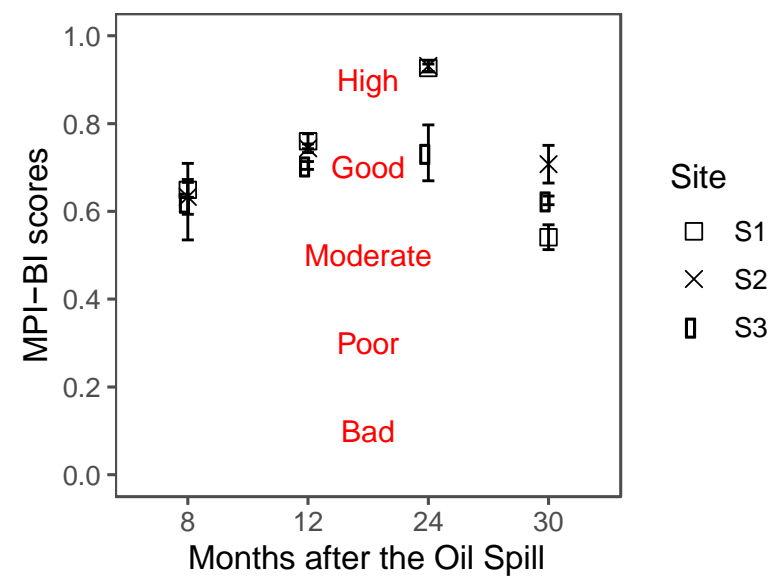

Figure 6. Multimetric phytoplankton index for biotic integrity (mean $\pm S E$ ) in affected sites after 8 - 30 months from the oil spill incident 


\section{Time series analysis of environmental parameters before and after the spill}

Earlier analysis revealed that $C h l a$ is pressure specific. Hence, we used $C h l a$ to indicate trophic status changes in the southern coast of Mactan before and after the spill. We also correlated $C h l a$ to other environmental parameters to determine whether the changes in the trophic status can be attributed to the oil spill or to natural conditions in the environment. However, this study does not give a claim on the direct nor the isolated effect of oil spill on the Chl a changes. Instead, this study attempted to estimate, based on the evidence gathered, the trend of Chl a before and after the oil spill considering the role of other environmental and meteorological factors such as the particulate organic carbon $(P O C)$, photosynthetically active radiation $(P A R)$, sea surface temperature $(S S T)$, air temperature $(A T)$, relative humidity $(R H)$, precipitation $(P)$, and mean sea level pressure $(M S L P)$. These factors may play different roles in the variation of $C h l a$.

Fig. 7 shows the temporal patterns of $C h l a$ and the other environmental parameters. One-way ANOVA showed significant monthly and seasonal variations of all the parameters $(\mathrm{p}<0.05)$. Based on the pooled means in pre spill $(1-18$ months before the spill) and post spill ( $1-26$ months after the spill) conditions, higher Chl $a$ and $P O C$ were observed after the oil spill incident $(\mathrm{p}<0.01)$, while the other parameters showed no significant difference before and after the oil spill. This suggests a possible contribution of the oil spill impact to the changes of $C h l a$ and $P O C$ in the affected sites.
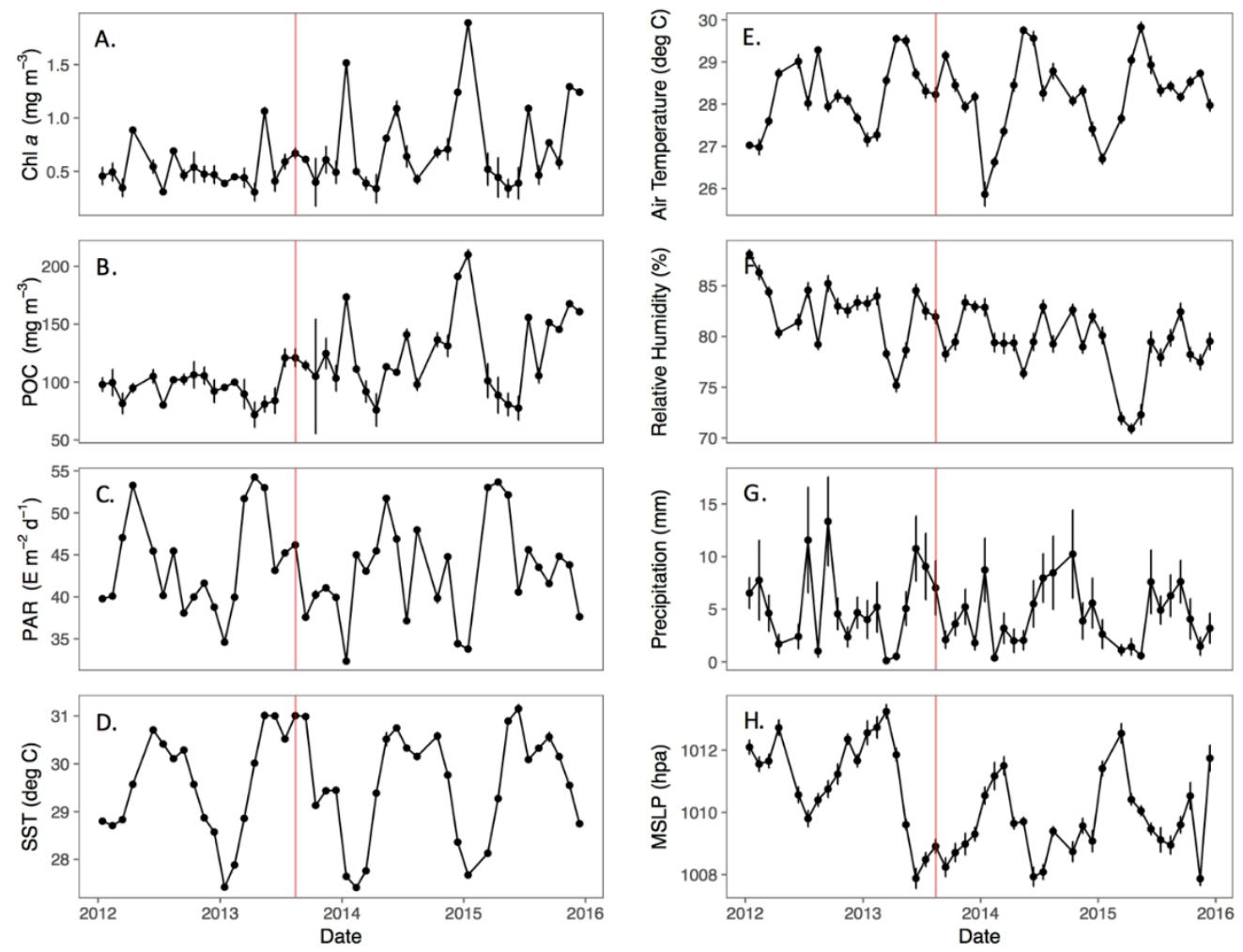

Figure 7. Temporal variation of $(A)$ chlorophyll a level, $(B)$ particulate organic carbon, $(C)$ photosynthetically active radiation, $(D)$ sea surface temperature, $(E)$ air temperature, $(F)$ relative humidity, $(G)$ precipitation, and $(H)$ mean sea level pressure. Remotely sensed estimates $(A-D)$ are reported as pooled mean (mean $\pm S E$ ) of the observed values in the affected sites. Meteorological data $(E-H)$ from PAGASA-DOST are reported as monthly average (mean $\pm S E$ ) of the values collected in the Mactan Station. The vertical line indicates the date of oil spill incidence 
Based on the Pearson correlation analysis, Chl $a$ was positively correlated to $A T$ $(r=0.45)$ and PAR $(r=0.46)$ in the pre spill condition. However, it was negatively correlated to both parameters $(r=-0.42$ and -0.52 , respectively) in post spill condition. A positive correlation between $C h l a$ and POC $(r=0.88)$ was also observed in the post spill condition.

We also used PCA to explore further the variability of the environmental parameters before and after the spill. About $91.3 \%$ of the total variance was explained by the first four PC axes as shown in the projections of the environmental parameters before and after the spill on different PC axes in Fig. 8. PC1 and PC2 relate to hydrographic and meteorological conditions. PC1 explained $38.9 \%$ of the total variance and significantly explained the variability of air temperature and photosynthetically active radiation with Pearson correlation coefficients $(r)$ of 0.48 and 0.5 , respectively. PC2 explained $27.2 \%$ of the total variance and was related to mean sea level pressure and sea surface temperature ( $r=0.60$ and -0.51 , respectively). Both components did not significantly vary before and after the spill ( $\mathrm{p}>0.05)$. On the other hand, PC3 and PC4 are related to the trophic condition as it best explained the variability of Chla with $r$ value of 0.57 and 0.47 , respectively. PC3 was also positively related to particulate organic carbon $(r=0.49)$. There were significant differences in PC3 and PC4 between pre and post spill conditions ( $p<0.01$ ), suggesting a possible shift in trophic status in the southern coast of Mactan Island after the oil spill incidence.
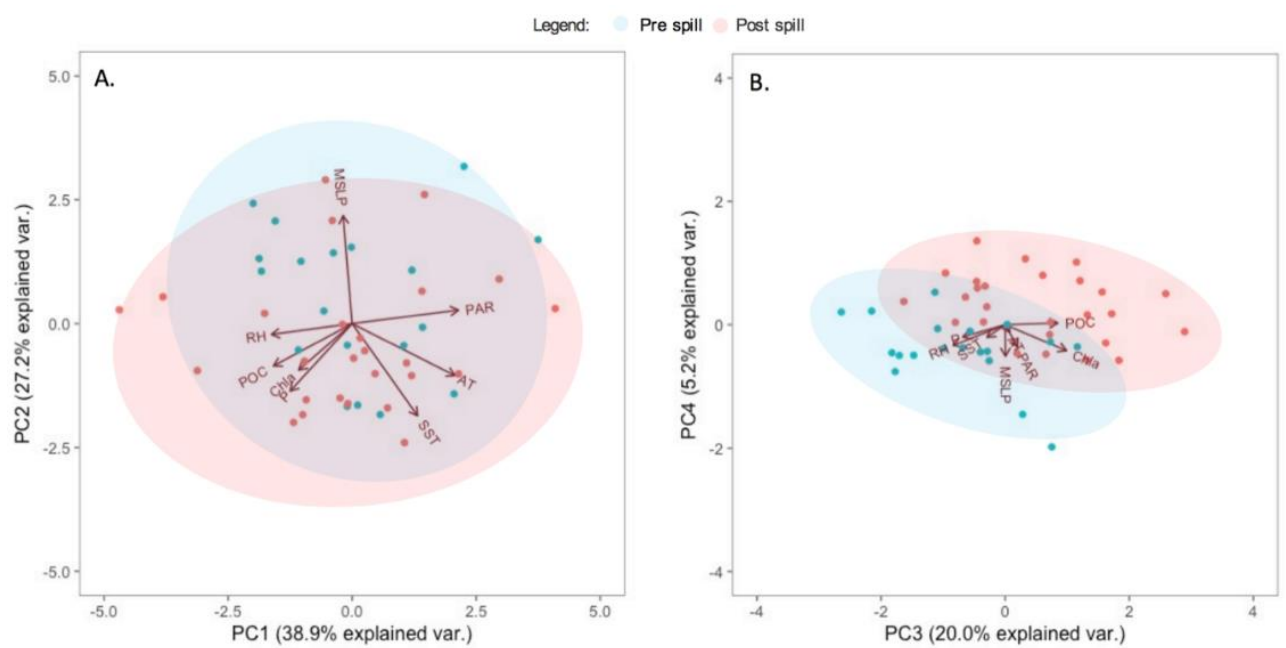

Figure 8. Projection of the chlorophyll a level (Chl a), particulate organic carbon (POC), photosynthetically active radiation (PAR), sea surface temperature (SST), air temperature (AT), relative humidity $(R H)$, precipitation $(P)$, and mean sea level pressure $(M S L P)$ on the $(A) P C 1$ and $P C 2$, and (B) PC3 and PC4 axes. Ellipses (95\% confidence) represent the projections of the variables in pre spill and post spill conditions

\section{Discussion}

The affected sites had an increase in one or more taxonomic groups, changing the phytoplankton community composition. Certain phytoplankton genera dominate during an oil-spill event, which could be used as indicators of the marine phytoplankton community stressed by oil components (Hallare et al., 2011). Three of them (i.e. Chaetoceros, Rhizosolenia, and Skeletonema) were present in the affected sites. 
Results also showed the dominance of diatoms and dinoflagellates in affected sites. Diatoms proliferated dominantly relative to dinoflagellates in more highly affected site. Unlike dinoflagellates, diatoms have been demonstrated to possess the ability to use oil as a carbon source even at low concentrations to propagate colonizing an area affected by oil spillage (El-Sheekh et al., 2000). They also possess silica frustules that protect them from acute lethal effects of oil compared to the other naked phytoplankton (Ikavalko et al., 2005). Conversely, some studies show that diatom growth is suppressed during the oil spill and laboratory experiments (Harrison et al., 1986; Lee and Page, 1997) because the structure of diatoms allows them to absorb hydrocarbons more readily thereby enabling subsequent toxicity as well as hindering reproduction (Kustenko, 1981). Centric diatoms (e.g. Coscinodiscus, Rhizosolenia, Skeletonema) predominates pennate diatoms (e.g. Navicula, Nitzschia, Pleurosigma) due to the fact that the latter are more sensitive to pollutants (Perez et al., 2010). However, this was not observed in the affected sites since centric diatoms were found at very low densities.

The findings also suggest that phytoplankton communities in affected and reference sites after $8-30$ months from the spill had relatively similar abundance and richness, which results in no variation in the diversity. The result suggests no apparent change in phytoplankton communities from the reference condition throughout the investigated period. However, remotely sensed chlorophyll $a$ estimates in the affected sites were higher than in the reference site, suggesting higher phytoplankton biomass and hence a higher trophic state in the oil spill affected sites. Existing studies on the effect of oil spill towards phytoplankton communities showed unclear and contradictory results - e.g. no change in the number of planktonic population (Johansson et al., 1980; Khalaf et al., 2006), reduction in the density, the number of species, diversity and ecophysiological indices (Batten et al., 1998), and proliferation of phytoplankton (Hallare et al., 2011) in an oil spill affected site.

Temporal variation was demonstrated in phytoplankton diversity, where it showed a significant increasing trend after the spill. These findings suggest a possible shift in taxonomic groups that change the composition of the phytoplankton community, subsequently increasing the phytoplankton diversity and possibly the biomass after the spill incidence.

One limitation in our in situ assessment of composition is that it is biased not only on the armored or those with tests but the sampling is also biased on those net phytoplankton that is usually in the microphytoplankton size. The phytoplankton or the autotrophic bacteria and phytoplankton smaller than 20 microns are not captured in the analysis. Another limitation of the assessment is the condition that the southern coast of Mactan is chronically exposed also to oil being a navigational route of ships while the reference is not that might contribute to the variation observed between the sites.

Oil spill affected sites may return to their reference condition just within two weeks (Johansson et al., 1980) or more than six months (Spooner, 1977) after the oil spill. Recovery of an affected site is greatly influenced by a myriad of factors such as coastal topography, water-body characteristics, oil composition, and its fate, and also abiotic and biotic factors. It is possible that the spilled oil had already been dispersed by spreading, emulsification, dissolution, evaporation, sedimentation, adsorption (Bartha and Atlas, 1977), photo-oxidation (Lacaze and de Naïde, 1976), and bacterial degradation (McGenity et al., 2012; Bensig et al., 2014). However, the recovery of phytoplankton communities after the occurrence of the oil spill cannot be inferred from the findings due to the absence of pre oil spill data. 
The observed differences in $C h l a$ and $P O C$ between pre and post spill condition suggest a possible contribution of the oil spill impact to the changes of trophic state in the affected coastal water of Mactan Island. The correlative patterns of the environmental parameters to the changes of $C h l a$ showed to differ between pre and post spill conditions. This may suggest possible interactive effects of the oil spill and meteorological factors on the variability of $C h l a$. It is also possible that the change in the Chl $a$ after the oil spill may not be due to its interaction with environmental parameters but could be the previous events that happened in the area, i.e oil spill incidence. For instance, the variability of $C h l$ $a$ in areas with natural disturbance is not affected by the seasonal change of SST but is mainly dependent on the current action of the ecosystem such as nutrients and chemical composition of the area (Nababan et al., 2016). In this case, the probability of contributing to the oil spill changed the chemical composition of the area and may lead to the effect of the oil on the affected coastal waters.

Time-series analysis showed that there was a change in the monthly distribution of Chl $a$ in the affected area. No significant change was observed during first five months of the oil spill when compared to the previous years of the same months, respectively. However, a significant increase occurred 6 months after the oil spill. There was a lag time before significant changes in the Chl $a$ was observed. The time interval of this study confirmed the findings of Sheng et al. (2011) that Chl $a$ increase at an average of 6 months. In other studies, an increase in $C h l a$ was observed after 5.5 months (Vargo et al., 1982), 7 months (Riaux-Gobin, 1985), and 9 months (Sheng et al., 2011). While there was no change in $C h l a$ in this study during the first five months of the oil spill, findings suggest the decrease of $C h l a$ for about 2 weeks (Lee et al., 2009) while, in other study, for about 7 weeks (Wang, 2015).

Increase of the phytoplankton in a time interval is possibly due to the oil weathering in the area and the decreased zooplankton primarily feeding to the phytoplankton (Lee et al., 2009). It has also been proven that zooplankton decreased significantly after the oil spill and maybe the reason for lesser herbivory in the area (Johansson et al., 1980). Also, the chance of the increased bacteria feeding the oil, as evidenced by increased nitrogen products of bacterial metabolism, enhanced the possibility of removing oil fractions in the area (Banks, 2003). Sheng et al. (2011) stated that the short-lived increase of phytoplankton may be the roles of reduced grazing pressure, decomposition of dead organisms, competitive and tolerant phytoplankton, and stimulating effect of oil to phytoplankton.

Surprisingly, there was still evidence of $C h l a$ increase in the affected area even after the span of 18,28 , and 29 months. This observation is speculated to be a result of the long term effect of the oil spill. It is likely that long term changes in the Chl a may be attributed to the oil spill residue that may still be present in the underlying sediment of the affected coastal waters. Duan et al. (2018) observed the presence of the residual oil in the sediment at Bay Jimmy five years after the oil spill. They observed after the oil spill that there is a significant increase in concentrations of polycyclic aromatic hydrocarbons (PAH), n-alkenes, and total petroleum hydrocarbon. A number of studies have demonstrated the negative effect of PAH on the phytoplankton biomass (Pelletier et al., 2006; Kamalanathan et al., 2018). Degradation of these oil spill residue components may provide a potential source of carbon for phytoplankton growth and productivity, which may explain the long term increase of $C h l a$. However, this hypothesis is impossible to test due to a lack of continuous field measurements. 


\section{Conclusion}

This study evaluated the multimetric phytoplankton-based ecological health status of the coastal water of Mactan Island after $8-30$ months from the oil spill incidence. The important findings of this study were as follows: (1) Phytoplankton community structure in affected and reference sites did not differ in abundance and richness that resulted in no variation in the diversity between sites. However, the difference in abundance between sites can be significantly different depending on the dates. Furthermore, the dominance of the major taxonomic groups had shifted that changes the phytoplankton community composition, subsequently increasing the phytoplankton diversity over time after the spill incidence. Higher chlorophyll $a$ was observed in oil spill affected sites. (2) Multivariate analysis showed that the observed spatial and temporal variation can be best explained by phytoplankton relative abundance diversity and trophic state, which can be used to determine the MPI-BI. Based on the MPI-BI scores, the health status of the affected sites after $8-30$ months from the oil spill incident was generally in good condition. (3) A time-series analysis of chlorophyll $a$ concentration revealed the difference between pre and post spill conditions that may suggest the effect of oil spill on the trophic state in the affected coastal water. Overall, the health status of the affected coastal water may be affected by oil as indicated by the increased level of chlorophyll $a$ in the post spill condition. However, the affected coastal water may also undergo a certain level of recovery from the oil spill stress as suggested by the similarity of the phytoplankton community structure to the reference site. Further study is recommended to evaluate the long term chronic effects of oil spill on phytoplankton community and primary productivity, but this requires continuous field measurements to verify the cause of the changes.

Acknowledgements. We would like to thank the University of the Philippines Cebu (Creative Work and Research Grant) for the funding. We also thank Monique Eloise Mercado for sharing the meteorological data collected from PAGASA-DOST.

\section{REFERENCES}

[1] Arnold, J. B. (2019): ggthemes: Extra Themes, Scales and Geoms for 'ggplot2'. - R package version 4.2.0.

[2] Baith, K., Lindsay, R., Fu, G., McClain, C. R. (2001): SeaDAS, a data analysis system for ocean-color satellite sensors. - EOS Transactions American Geophysical Union 82: 202.

[3] Banks, S. (2003): SeaWiFS satellite monitoring of oil spill impact on primary production in the Galápagos Marine Reserve. - Marine Pollution Bulletin 47(7): 325-330.

[4] Barbour, M. T., Swietlik, W. F., Jackson, S. K., Courtemanch, D. L., Davies, S. P., Yoder, C. O. (2000): Measuring the attainment of biological integrity in the USA: a critical element of ecological integrity. - Hydrobiologia 422/423: 453-464.

[5] Bartha, R., Atlas, R. M. (1977): The Microbiology of Aquatic Oil Spills. - Advances in Applied Microbiology 22: 225-266.

[6] Batten, S. D., Allen, R. J. S., Wotton, C. O. M. (1998): The effects of the Sea Empress oil spill on the plankton of the Southern Irish Sea. - Marine Pollution Bulletin 36(10): 764774.

[7] Becker, R. A., Wilks, A., Brownrigg, R., Minka, T. P., Deckmyn, A. (2018): maps: Draw Geographical Maps. - R package version 3.3.0.

[8] Behrenfeld, M. J., Falkowski, P. G. (1997): Photosynthetic rates derived from satellitebased chlorophyll concentration. - Limnology and Oceanography 42: 1-20. 
[9] Bensig, E. O., Edullantes, B., Silapan, J. R., Narsico, J. T. (2014): Oil degrading and heterotrophic bacteria composition in the oil-spilled affected mangrove forest sediment in Mactan Island, Central Philippines. - International Journal of Biosciences 5(8): 141-146.

[10] Bolognesi, C., Perrone, E., Roggieri, P., Sciutto, A. (2006): Bioindicators in monitoring long term genotoxic impact of oil spill: Haven case study. - Marine Environmental Research 62: S287-S291.

[11] Duan, J., Liu, W., Zhao, X., Han, Y., O’Reilly, S., Zhao, D. (2018): Study of residual oil in Bay Jimmy sediment 5 years after the Deepwater Horizon oil spill: persistence of sediment retained oil hydrocarbons and effect of dispersants on desorption. - Science of the Total Environment 618: 1244-1253.

[12] El-Sheekh, M. M., El-Naggar, A. H., Osman, M. E. H., Haieder, A. (2000): Comparative Studies on the Green Algae Chlorella homosphaera and Chlorella vulgaris with Respect to Oil Pollution in the River Nile. - Water, Air, and Soil Pollution 124(1-2): 187-204.

[13] Falkowski, P. (2012): Ocean science: The power of plankton. - Nature 483(7387): S17S20.

[14] Farrington, J. W. (2013): Oil Pollution in the Marine Environment I: Inputs, Big Spills, Small Spills, and Dribbles. - Environment: Science and Policy for Sustainable Development 55(6): 3-13.

[15] Farrington, J. W. (2014): Oil Pollution in the Marine Environment II: Fates and Effects of Oil Spills. - Environment: Science and Policy for Sustainable Development 56(4): 16-31.

[16] Flores, M. J., Silapan, J., Edullantes, B. (2020): Effect of the MV Saint Thomas Aquinas on zooplankton composition and abundance in Mactan Island, Cebu, the Philippines. Journal of Nature Studies 19(1): 105-119.

[17] García Pérez, J. D. (2003): Early socio-political and environmental consequences of the Prestige oil spill in Galicia. - Disasters 27(3): 207-23.

[18] Gesteira, J. L. G., Dauvin, J. C. (2000): Amphipods are Good Bioindicators of the Impact of Oil Spills on Soft-Bottom Macrobenthic Communities. - Marine Pollution Bulletin 40(11): 1017-1027.

[19] Gin, K. Y. H., Kamrul Huda, M., Kiat Lim, W., Tkalich, P. (2001): An Oil Spill-Food Chain Interaction Model for Coastal Waters. - Marine Pollution Bulletin 42(7): 590-597.

[20] Guiry, M. D., Guiry, G. M. (2016): AlgaeBase. - World-wide electronic publication, National University of Ireland, Galwa, http://www.algaebase.org.

[21] Hallare, A. V, Lasafin, K. J. A., Magallanes, J. R. (2011): Shift in Phytoplankton Community Structure in a Tropical Marine Reserve Before and After a Major Oil Spill Event. - International Journal Environmental Research 5(3): 651-660.

[22] Harrison, P. J., Cochlan, W. P., Acreman, J. C., Parsons, T. R., Thompson, P. A., Dovey, H. M., Xiaolin, C. (1986): The effects of crude oil and Corexit 9527 on marine phytoplankton in an experimental enclosure. - Marine Environmental Research 18(2): 93109.

[23] Hijmans, R. J. (2020): raster: Geographic Data Analysis and Modeling. - R package version 3.3-13.

[24] Ikavalko, J., Gerdes, B., Hiukka, R. (2005): Effects of crude oil on arctic sea ice biota, an experimental study. - Phycologia 44: 48-58.

[25] International Maritime Organization, United Nations (2009): IMO/UNEP guidance manual on the assessment and restoration of environmental damage following marine oil spills. Environment Programme, International Maritime Organization.

[26] Johansson, S., Larsson, U., Boehm, P. (1980): The Thesis oil spill impact on the pelagic ecosystem. - Marine Pollution Bulletin 11(10): 284-293.

[27] Kamalanathan, M., Xu, C., Schwehr, K., Bretherton, L., Beaver, M., Doyle, S. M., Genzer, J., Hillhouse, J., Sylvan, J. B., Santschi, P. (2018): Extracellular enzyme activity profile in a chemically enhanced water accommodated fraction of surrogate oil: toward understanding microbial activities after the Deepwater Horizon oil spill. - Frontiers in Microbiology 9: 798. 
[28] Khalaf, G., Nakhlé, K., Abboud-Abi Saab, M., Tronczynski, J., Mouawad, R., Fakhri, M. (2006): Preliminary results of the oil spill impact on Lebanese coastal waters. - Lebanese Science Journal 7(2): 135-153.

[29] Kustenko, N. G. (1981): Effect of low oil concentrations on Spermatogonangii and Auxospores in three species of marine diatoms. - Okeanologiya/Oceanology (Moscow) 21: 366-369.

[30] Lacaze, J. C., Villedon de Naïde, O. (1976): Influence of illumination on phytotoxicity of crude oil. - Marine Pollution Bulletin 7(4): 73-76.

[31] Lee, R. F., Page, D. S. (1997): Petroleum hydrocarbons and their effects in subtidal regions after major oil spills. - Marine Pollution Bulletin 34(11): 928-940.

[32] Lee, C. I., Kim, M. C., Kim, H. C. (2009): Temporal variation of chlorophyll a concentration in the coastal waters affected by the Hebei Spirit oil spill in the West Sea of Korea. - Marine Pollution Bulletin 58(4): 496-502.

[33] Li, Y., Hu, C., Quigg, A., Gao, H. (2019): Potential influence of the Deepwater Horizon oil spill on phytoplankton primary productivity in the northern Gulf of Mexico. Environmental Research Letters 14: 094018.

[34] McGenity, T. J., Folwell, B. D., McKew, B. A., Sanni, G. O. (2012): Marine crude-oil biodegradation: a central role for interspecies interactions. - Aquatic biosystems 8(1): 10.

[35] Nababan, B., Rosyadi, N., Manurung, D., Natih, N. M., Hakim, R. (2016): The Seasonal Variability of Sea Surface Temperature and Chlorophyll-a Concentration in the South of Makassar Strait. - Procedia Environmental Sciences 33: 583-599.

[36] NASA Goddard Space Flight Center, Ocean Biology Processing Group (2014): Seaviewing Wide Field-of-view Sensor (SeaWiFS) Ocean Color Data. - NASA OB.DAAC, Greenbelt, MD, USA. http://doi.org/10.5067/ORBVIEW-2/SEAWIFS_OC.2014.0. Accessed 2018/10/21. Maintained by NASA Ocean Biology Distibuted Active Archive Center (OB.DAAC), Goddard Space Flight Center, Greenbelt MD.

[37] Oksanen, J., Blanchet, F. G., Friendly, M., Kindt, R., Legendre, P., McGlinn, D., Minchin, P. R., O'Hara, R. B., Simpson, G. L., Solymos, P., Stevens, M. H., Szoecs, E., Wagner, H. (2019): vegan: Community Ecology Package. - R package version 2.5-6.

[38] Ozhan, K., Parsons, M. L., Bargu, S. (2014): How Were Phytoplankton Affected by the Deepwater Horizon Oil Spill? - BioScience 64(9): 829-836.

[39] Parsons, M. L., Morrison, W., Rabalais, N. N., Turner, R. E., Tyre, K. N. (2015): Phytoplankton and the Macondo oil spill: A comparison of the 2010 phytoplankton assemblage to baseline conditions on the Louisiana shelf. - Environmental pollution 207: $152-60$

[40] Pelletier, E., Sargian, P., Payet, J., Demers, S. (2006): Ecotoxicological effects of combined UVB and organic contaminants in coastal waters: a review. - Photochemistry and Photobioliology 82: 981-93.

[41] Perez, P., Fernandez, E., Beiras, R. (2010): Fuel toxicity on Isochrysis galbana and a coastal phytoplankton assemblage: Growth rate vs. variable fluorescence. - Ecotoxicology and Environmental Safety 73(3): 254-261.

[42] R Core Team (2019): R: A language and environment for statistical computing. - R Foundation for Statistical Computing, Vienna, Austria. https://www.R-project.org/.

[43] Reynolds, C. S. (2006): Ecology of phytoplankton. - Cambridge: Cambridge University Press.

[44] Riaux-Gobin, C. (1985): Long-term changes in microphytobenthos in a Brittany estuary after the "Amoco Cadiz" oil spill. - Marine Ecology Progress Series 24: 51-56.

[45] Sadaba, R., Niego, A. G. (2016): Assessment on the effects of an oil spill in the mangroves of Cordova, Cebu, Philippines. - The Malaysian Forester 79(1\&2): 144-156.

[46] Sheng, Y., Tang, D., Pan, G. (2011): Phytoplankton bloom over the Northwest Shelf of Australia after the Montara oil spill in 2009. - Geomatics, Natural Hazards and Risk 2(4): 329-347.

[47] Spooner, M. F. (1977): Oil spill in Hong Kong. - Marine Pollution Bulletin 8(3): 62-65. 
[48] Suderman, K., Thistle, D. (2004): The relative impacts of spills of two alternative fuels on the microalgae of a sandy site: a microcosm study. - Marine Pollution Bulletin 49(5): 473478.

[49] Surís-Regueiro, J. C., Garza-Gil, M. D., Varela-Lafuente, M. M. (2007): The Prestige oil spill and its economic impact on the Galician fishing sector. - Disasters 31(2): 201-215.

[50] Teng, L., Zhang, B., Liu, X., Bai, C., Zhang, J., Tan, D., Huang, P. (2014): Development and Use of a Phytoplankton-Index of Biotic Integrity to Assess Yongjiang River Ecosystem Health. - Polish Journal of Environmental Studies 23(3): 901-908.

[51] Vargo, G., Hutchins, M., Almquist, G. (1982): The effect of low, chronic levels of no. 2 fuel oil on natural phytoplankton assemblages in microcosms: 1 . Species composition and seasonal succession. - Marine Environmental Research 6(4): 245-264.

[52] Verlecar, X. N., Desai, S. (2004): Phytoplankton Identification Manual. - First Dona Paula, Goa: National Institute of Oceanography.

[53] Verlecar, X. N., Desai, S. R., Sarkar, A., Dalal, S. G. (2006): Biological indicators in relation to coastal pollution along Karnataka coast, India. - Water Research 40(17): 33043312.

[54] Wang, D. (2015): Remote Sensing-Based Study on the Temporal Variations in Chlorophyll-a Concentration After Confo Oil Spill in Bohai Sea. - Journal of the Indian Society of Remote Sensing 43(1): 133-142.

[55] Wickham, H., Averick, M., Bryan, J., Chang, W., D'Agostino McGowan, L., François, R., Grolemund, G., Hayes, A., Henry, L., Hester, J., Kuhn, M., Pedersen, T. L., Miller, E., Milton Bache, S., Müller, K., Ooms, J., Robinson, D., Paige Seidel, D., Spinu, V., Takahashi, K., Vaughan, D., Wilke, C., Woo, K., Yutani, H. (2019): Welcome to the tidyverse. - Journal of Open Source Software 4(43): 1686. 